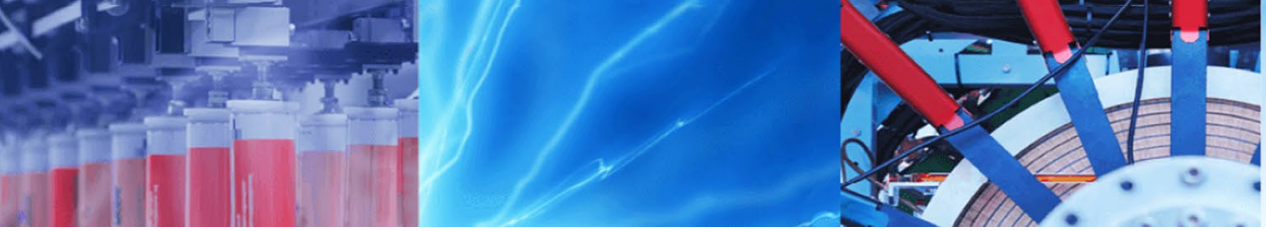

Case Study

\title{
Conducting exergy analysis by utilizing condenser waste heat in commercial type split air conditioner: a case study
}

\author{
Ali Kemal Cakir ${ }^{1}$ Bahtiyar Sansli ${ }^{2}$
}

Received: 22 October 2019 / Accepted: 4 January 2020 / Published online: 13 January 2020

(c) Springer Nature Switzerland AG 2020

\begin{abstract}
The results of this study showed that the modified version of the appliance integrated with the boiler exhibited an increased coefficient of performance (COP) during normal operation when compared with that of the original appliance during normal operation. Thus, the appliance could achieve a significant increase in efficiency while reducing electricity consumption and increasing capacity, thereby heating the water without additional expense. In current models in the market, there is a need for the user to program the timing of hot water using a controller and the appliance operates with a boiler system during the programmed times. These models are difficult to operate. However, once the controller is set, further adjustments are not required; this makes them user-friendly. Once the model has been programmed by the user, the appliance can no longer perform the heating or cooling function in the building while operating the boiler. This gives rise to losses in the comfort and regime of the building, while the appliance continues to consume electricity. Such problems are not recorded in the device as it conducts boiler heating-cooling function in parallel with each other and on the contrary, it continues to comfort the environment without pausing environment heating-cooling and consuming extra electricity while heating the water in the boiler and it also increases the performance of the device. As a result of the above calculations and the results obtained, the COP at the time of normal operation of the appliance was 2.89 and the COP of the appliance modified with the boiler at the time of operation was 4.54. The COP of the appliance increased approximately 1.6 times with the boiler modification. With this application, it has become possible to safeguard both the environment and the users by using domestic hot water for heating in commercial type split air conditioners. For energy saving providers, this value is quite good. This study is aimed at reducing energy consumption and increase efficiency.
\end{abstract}

$\triangle$ Ali Kemal Cakir, alikemalcan@hotmail.com; Bahtiyar Sansli, bahtiyarsansli@hotmail.com | 'Department of Mechanical Engineering, Faculty of Engineering and Architecture, Kastamonu University, Central Campus, PO Box 37200, Kastamonu, Turkey. ${ }^{2}$ Department of Mechanical Engineering, Faculty of Engineering, Karabük University, Karabük, Turkey. 
Graphic abstract Schematic description of the application

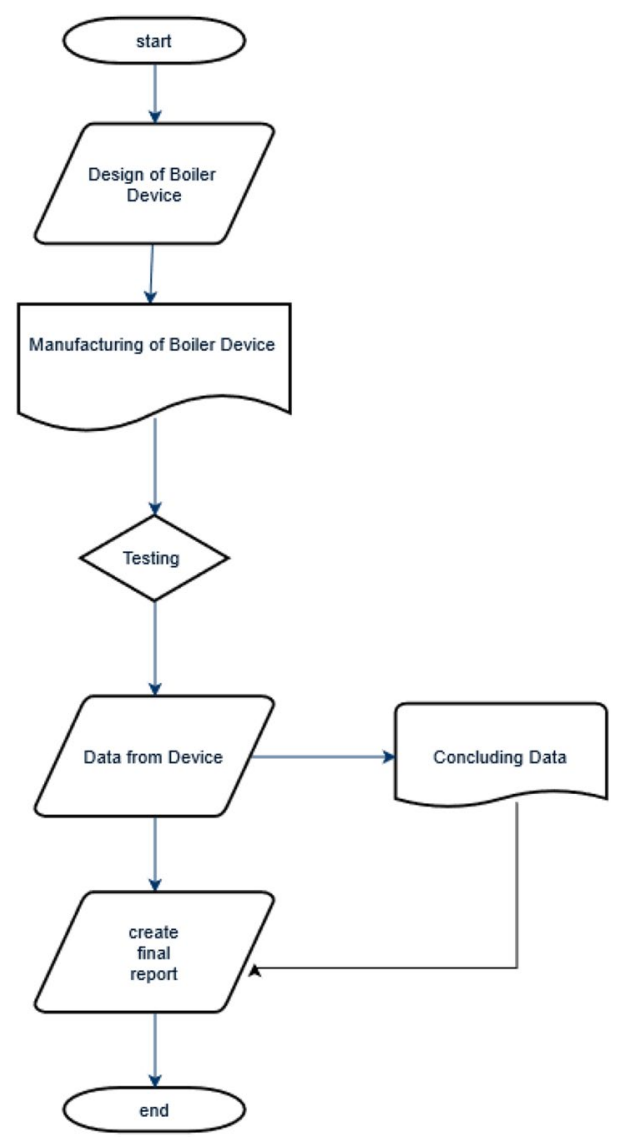

Keywords Split air conditioner - Exergy analysis · Heat pump · Efficiency - Thermodynamic

\section{Introduction}

Today, official facilities, residences, workplaces, and many other similar areas are in need of cooling and heating systems.

However, new savings are required to pay the cost of using hot water. Many cases related to the above discussions have been reported wherein energy consumption has increased, thereby increasing economic costs by increasing initial investment, operating, and maintenance expenditures. Taking these into consideration, to reduce both appliance diversity (initial investment costs) and other operating and maintenance costs, the highest performance has been achieved using only one appliance by minimizing the costs of boiler operation and heating-cooling functions.

Yilmaz and Aydin [12] made theoretical models of air-air, air-water, water-air and water-water heat pumps.
The main components of the system, evaporator, condenser, compressor and expansion valve elements were evaluated separately and their dimensions calculated.

Presently, air-source heat pumps (split air conditioners) that are widely used in residences, workplaces, hospitals, schools, and factories, meet the requirements of heating, cooling, and ventilation. These places also use boilers, solar energy, bath stoves, water heaters, and combi boilers for hot water. Thus, extra investment and operating costs are involved in producing hot water for use. Generally, electricity is consumed at a rate of $50 \%$ during heat conversion while heating the water. To eliminate these drawbacks and to reduce electricity consumption by split air conditioners, a boiler with a small modification is integrated onto the split air conditioners used in residences to produce hot water for use without affecting the heating and cooling efficiency and possibly increase it. Considering the fact that split air conditioners are used in $90 \%$ of the application areas and with the first investment cost for the boiler and hot water infrastructure; we aimed to reduce the electricity consumption of the split air conditioner and increase the efficiency of the appliance alongside the production of hot water for use. Thus, we aimed to produce hot water for use while performing the heating-cooling process using an air source heat pump.

The exergy efficiency is introduced based on a general definition of efficiency, and the balance of the cost is presented as an additional balance equation to be used in the performance analysis of energy systems [8].

Among energy efficiency optimization approaches, thermodynamics methodologies contribute toward the improvement of energy efficiency in manufacturing processes. Besides energy balance, exergy has been recently considered as a practical thermodynamics method for system's energy evaluation [11].

Bonnet et al. [3] reported that Stirling and Ericsson engines are suitable for micro-cogeneration applications, they operate without noise and are cheaper to maintain. It was stated that Ericsson engines can be preferable since they are cheap and energetically better. It is stated that Ericsson engine is used with natural gas combustion system. Energy exergy and ergonomic analysis are performed for the installation of such facility. The data obtained as a result of the study analysis showed that Ericsson engines are more suitable for micro-cogeneration applications. Ayhan et al. [1] established an experimental system for solar energy-assisted exergy analysis of heat pumps. Data were collected from studies conducted from June-August (1991). The heat pump system calculates the exergy yield and compares it with the different systems.

In the study of Kaynakli and Kilic [7], the first and second laws of thermodynamics were employed and performance analysis of a single-phase water-lithium bromide-sorption 
cooling system in the direction of variable parameters was performed. In the exergy analysis method of system performance, a mathematical model was constructed by taking each component in terms of exergy losses and total system loss of exergy.

Ceylan et al. [4] studied poplar lumber and lumber from moisture from 1.28 water mass/dry mass to 0.60 water mass/dry mass. During the drying cycle, the mass loss in the timber was examined. All data were stored on the computer during the drying process. Energy analysis was carried out to determine energy use. Exergy analysis is also used to determine the losses in the system. At the end of the study, it was found that the effect of two parameters on exergy losses in the evaporator and condenser was large, but the effect on exergy losses in the compressor and throttle valve was low. It is stated that as the temperature difference between the evaporator-environment and the cooled environment-condenser decreases, the efficiency of the second law will increase and the total exergy loss will decrease.

Bilgen and Takahashi [2] carried out an exergy analysis of heat pump-air conditioning devices. In this study, irreversibility forces caused by heat transfer and friction are taken into consideration. This is defined as a function of the parameters of the coefficient of performance based on the first law of thermodynamics. Accordingly, optimum values and efficiency coefficients based on exergy analysis were derived. In this study, a simulation program based on exergy analysis was used to simulate and evaluate experimental studies. A commercial heat pump with a nominal power of $959 \mathrm{~W}$ was used for experimental applications. It was stated that the COP value based on the first law varied between 7.40 and 3.85 and the exergy efficiency ranged between 0.37 and 0.25 .

Esen et al. [5] investigated the effect of pit depth on energy and exergy efficiency in ground source heat pumps. Horizontal soil heat exchangers are embedded in two different depths, $1 \mathrm{~m}$ and $2 \mathrm{~m}$. Exergy efficiency on these systems is obtained as $53.1 \%$ and $56.3 \%$ respectively. The energy efficiency was obtained as 2.5 and 2.8 respectively. It was established from the study that the increase in soil temperature during the heating season increases the energy and exergy efficiency of the system. In addition, the effects of the changes in ambient temperature on the exergy efficiency of the system were examined and it was seen that the exergy efficiency decreased while the ambient temperature increased.

Hepbasli et al. [6] in their study, when compared to other conventional earth-source heat pump systems, indicated that they have an important function for heating and cooling. In their study, 1.25-inch diameter and $50 \mathrm{~m}$ long soil heat exchangers were used and energy and exergy analyses of this system were performed. Cooling and heating loads of the system are given as $3.8 \mathrm{~kW}$ and $4.2 \mathrm{~kW}$ respectively. They stated that the exergy diagrams of the ground source heat pump provide quantitative information about the system.

Ozgener et al. [9] in their study made exergy analysis in terms of determining the potential for modelling and improvement of air source heat pumps. And they provide descriptive examples. Exergy losses of all components in the system were calculated on the basis of experimentally collected parameters. At the end of the study, the greatest irreversibility in the system is seen in the condenser, compressor, evaporator and expansion elements respectively.

To determine these aspects, the energy and exergy analyses of the system will be performed and the air source heat pump (split air conditioner) system will be checked for a significant energy saving and increased system efficiency. To investigate the effectiveness of the boilers installed in the system and the advantages they provide to the heat pump, analyses such as thermodynamics, cost, amortization and period of return on investment will be performed.

\section{Materials and methods}

A preliminary study was conducted using revised materials and materials required for the experimental setup.

\subsection{Boiler fabrication}

Barrel insulation was fabricated using 1-cm-thick insulation material, which is bonded on the 40-L barrel using an adhesive.

A copper pipe of $\sim 18-\mathrm{m}$ length and $3 / 8^{\prime \prime}$ diameter was bent and placed into the $40-\mathrm{L}$ barrel; the copper pipe countersank ends were passed through two holes on the barrel and connected to the appliance with two sleeve fittings.

\subsection{Fabrication of the external unit}

To prevent the ozone layer from any harm, the liquid tanks are filled with existing R22 gas in the external unit using a gas collecting apparatus. Thereafter, the external unit covers are removed and the delivery pipe on the external unit compressor is removed via oxy-fuel cutting. Copper pipes are removed using two elbows from the two holes drilled on the external unit back cover via oxy-fuel cutting.

Infrastructure fittings were completed by assembling the valves using T-type copper pipes on the pipes removed from the external unit. The ends of these connections are countersunk, and the valve is fitted using a sleeve and connected to the previously prepared boiler valve ends. 
The temperature on the appliance is measured to ensure its operation within certain pressures and to ensure its safety. The external unit fan control is provided by measuring the heat on the condensate return pipe on the external unit. In this way, the condensation pressure of the appliance remains stable at $\sim 4.5$ bar cooling. The external unit turns on the fan at $\sim 55^{\circ} \mathrm{C}$ and turns it off at $35^{\circ} \mathrm{C}$ to make the external unit condensation pressure stable.

A switch is provided to enable manual hot-cold selection on the appliance. An emergency switch is placed on the supply connections so that the appliance can be switched off during an emergency.

A switch is provided for manual hot-cold selection on the device. An emergency switch is placed on the supply connections so that the appliance can be switched off during an emergency.

After the connection of the copper pipe and cables between the internal and external units of the appliance, the appliance is vacuumed and manifold and leakage checks are performed. Using precision balance, the appliance is filled with the original gas amount and $0.15 \mathrm{~g}$ of R22 gas per meter of copper pipe used for the boiler is additionally added. The appliance is tested only after it is completely filled with gas and the electrical connections of the appliance are checked as can be seen in technical drawing in Fig. 1.

\subsection{Test run of the appliance and data collection}

After the connection of the appliance to the main power, the appliance is switched on via the emergency switch. To operate the appliance in the cooling mode, the bypass valve on the external unit is opened and the boiler shuttle valves are closed. The compressor pressurizes the R22 gas in the system and compresses it in the condenser through the expansion valve and attempts to transfer heat from the

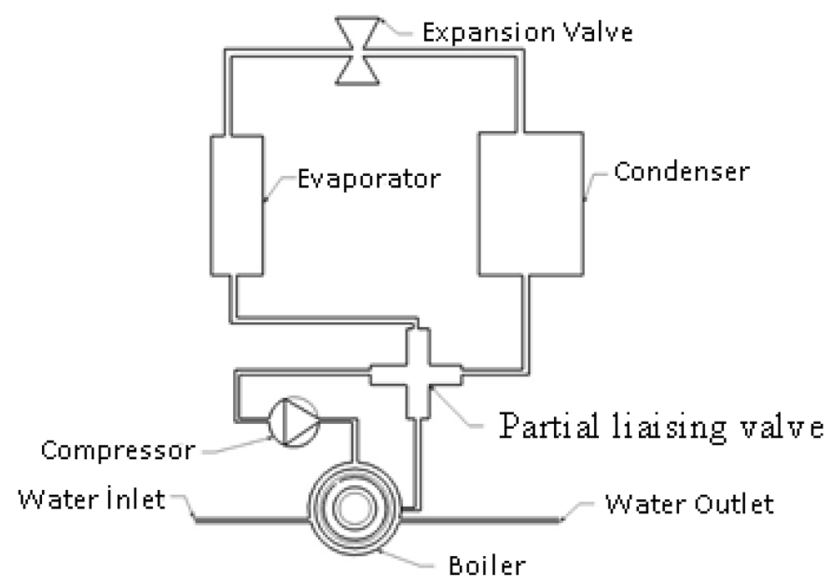

heated gas to the outside environment using a fan. The R22 gas, which is expelled in liquid form from the expansion valve, begins to re-expand in the evaporator and absorbs the heat in the inner space to cool the medium. In the boiler, the bypass valve must be closed and boiler shuttle valves must be open. In configuration with the boiler, the gas heated via compression in the compressor at the outer condenser is transferred to the water in the boiler instead of the outside air by directing the heat to the boiler before the condenser. This saves electricity and increases the efficiency and COP in the appliance. After operating the unit in normal cooling mode, the thermostat on the external unit is set by following the pressure indicator on the manometer. Current values are measured from external unit feeding cables using a clamp-on ammeter, and temperature values were measured from the determined points using a laser thermometer. Tables 1, 2, 3 and 4 show all the measured values. The appliance was first operated in cooling mode followed by heating mode.

\subsection{Saving amount of the appliance and its calculation}

R22 is the refrigerant used in the appliance. The refrigerant flow rate is shown as R22. The $h$ and $s$ values of the refrigeration cycle are obtained from the R22 fluid diagram according to its ( $\mathrm{p}-\mathrm{h}$ diagram of the $\mathrm{r} 22$ gas) temperature and pressure. $h_{0}$ and $s_{0}$ values for the cooling refrigeration cycle are obtained from the R22 table according to the fluid form of the refrigerant at $25^{\circ} \mathrm{C}$ and 1 bar pressure ambient condition. Table 5 show the values for the cooling process of refrigerant [10].

\section{Results and discussion}

From calculations and the results obtained, the COP at the time of normal operation of the existing system was 2.89 and the COP of the applied system with the boiler at the time of operation was 4.54 (Fig. 2). It was found that the system applied increased the COP value of the device by 1.6 times.

\subsection{Energy calculations for the existing system}

For the existing system, the measuring points given in Fig. 3 are used as a reference in energy calculations. Table 6 lists the data of measurement points.

For $6^{\circ} \mathrm{C}$ and 4.5 bars;

$h_{4 \text { liq }}=207.092 \quad s_{4 \text { liq }}=1.025$

Fig. 1 Technical drawing of the appliance 

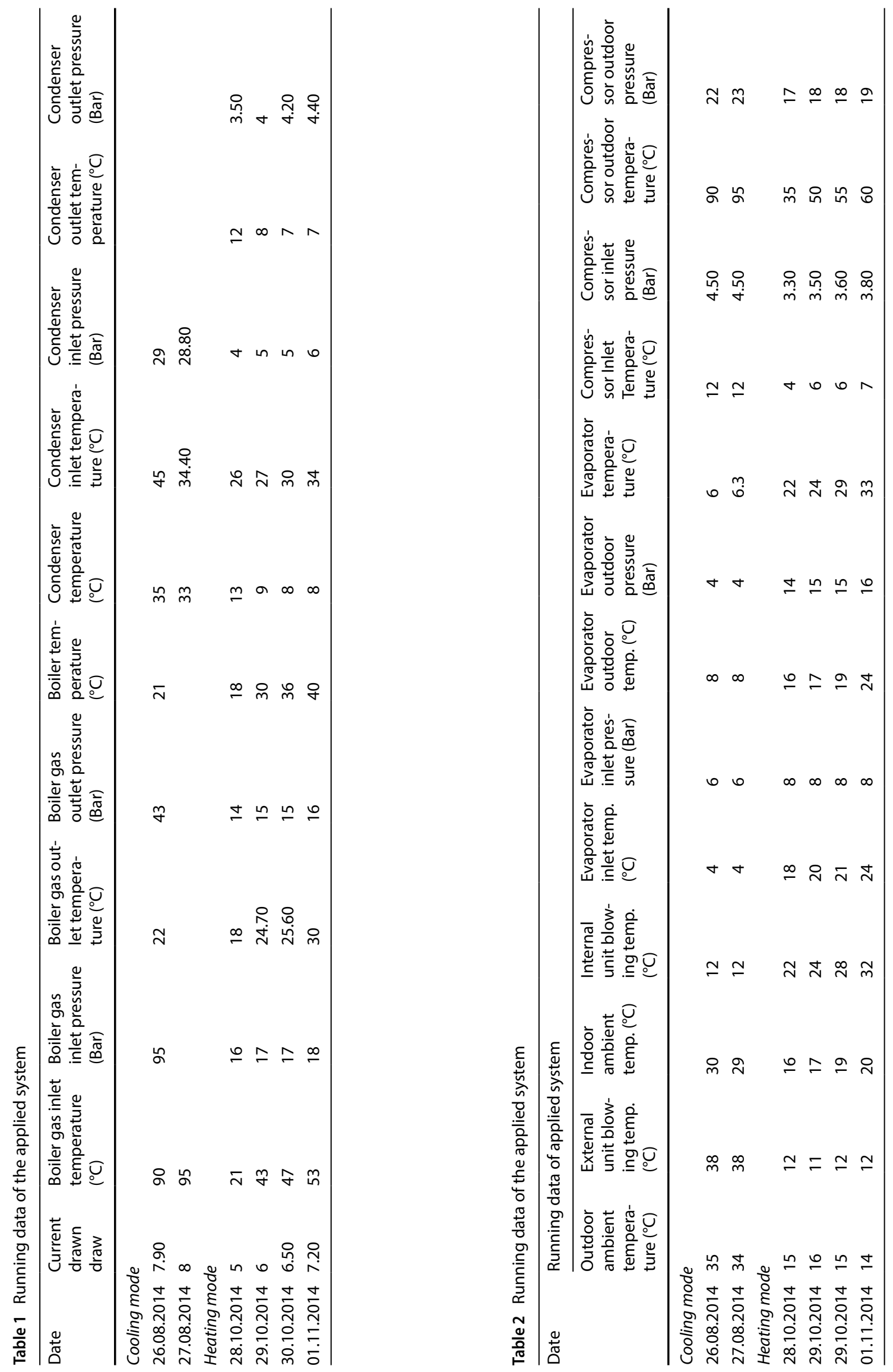
Table 3 Running data of the existing system

\begin{tabular}{|c|c|c|c|c|c|c|c|c|c|}
\hline Date & Amp draw & $\begin{array}{l}\text { Condenser } \\
\text { temperature } \\
\left({ }^{\circ} \mathrm{C}\right)\end{array}$ & $\begin{array}{l}\text { Condenser } \\
\text { inlet tem- } \\
\text { perature } \\
\left({ }^{\circ} \mathrm{C}\right)\end{array}$ & $\begin{array}{l}\text { Condenser } \\
\text { inlet pres- } \\
\text { sure (Bar) }\end{array}$ & $\begin{array}{l}\text { Condenser } \\
\text { outlet } \\
\text { temperature } \\
\left({ }^{\circ} \mathrm{C}\right)\end{array}$ & $\begin{array}{l}\text { Condenser } \\
\text { outlet pres- } \\
\text { sure (Bar) }\end{array}$ & $\begin{array}{l}\text { Outdoor } \\
\text { ambient } \\
\text { temperature } \\
\left({ }^{\circ} \mathrm{C}\right)\end{array}$ & $\begin{array}{l}\text { External unit } \\
\text { blowing } \\
\text { temperature } \\
\left({ }^{\circ} \mathrm{C}\right)\end{array}$ & $\begin{array}{l}\text { Indoor } \\
\text { ambient } \\
\text { tempera- } \\
\text { ture }\left({ }^{\circ} \mathrm{C}\right)\end{array}$ \\
\hline \multicolumn{10}{|c|}{ Cooling mode } \\
\hline 26.08 .2014 & 9.80 & 48 & 95 & 22 & 43 & 21 & 35 & 45 & 29 \\
\hline 27.08 .2014 & 10.20 & 46.60 & & & & & 33 & 34.40 & 28.80 \\
\hline \multicolumn{10}{|c|}{ Heating mode } \\
\hline 28.10 .2014 & 8 & 20.50 & & & & & 15 & 20 & 17 \\
\hline 29.10 .2014 & 10 & 15.50 & & & & & 15.40 & 14.50 & 19 \\
\hline 30.10 .2014 & 11 & 15 & & & & & 15.40 & 14.30 & 22 \\
\hline 01.11 .2014 & 10 & 15 & & & & & 15.50 & 14.30 & 21 \\
\hline
\end{tabular}

$h_{4 \text { vap }}=410.662 \quad S_{4 \text { vap }}=0.054$

$h_{4}=h_{4 \text { liq }}+x\left(h_{4 \text { vap }}-h_{4 \text { liq }}\right)$

$253.682=207.092+x(410.662-207.092)$

$x=0.228 \quad \% 22.8$

$s_{4}=s_{4 \text { liq }}+x\left(s_{4 \text { vap }}-s_{4 \text { liq }}\right)$

The cooling load of $6.59 \mathrm{~kW}$ is obtained from the production company catalog of the appliance. We can find the value of $\dot{m}$ using of Formula 5 in evaporator.

$\mathrm{Q}_{\mathrm{E}}=\dot{m}_{\mathrm{R} 22}\left(\mathrm{~h}_{5}-\mathrm{h}_{4^{\prime}}\right)$

In order to find the energy for $1-5$ points, where $Q$ is calculated using the following Formula 6.

$Q(n)=\dot{m}_{R 22} \times h(n)$

The measurement results obtained from the appliance and calculation values are shown in Table 7.

$W_{\text {comp }}=\dot{m}_{R 22}\left(h_{2}-h_{1}\right)$

The COP of the device is calculated by the ratio of the evaporator load to the compressor load as Formula 8.

$C O P_{\text {existing system }}=\frac{\dot{Q}_{\text {Evap }}}{W_{\text {Comp }}}$

COP and corresponding values for the existing system is shown in Table 8.

\subsection{Energy calculations of the applied system}

In the applied system, the measuring points shown in Fig. 4 are used as a reference in energy calculations. $h_{5 \text { liq }}$ $s_{5 \text { liq, }}, h_{5 \text { vap }}, s_{5 \text { vap }}$ are calculated through interpolation data from R22 Diagram. Table 9 shows the measurement points and data for the applied system. Table 9 shows measurement points and data for the applied system with the s (entropy) data.

For $4^{\circ} \mathrm{C}$ and 6 bars;

$h_{5 \text { liq }}=204.715, \quad s_{5 \text { liq }}=1.016$

$h_{5 \text { vap }}=406.049, \quad S_{5 \text { vap }}=1.738$

$h_{5}=h_{5 \text { liq }}+x\left(h_{5 \text { vap }}-h_{5 \text { liq }}\right)$

$243.101=204.715+x(406.049-204.715)$

$x=0.19 \% 19$

$s_{5}=s_{5 l i q}+x\left(s_{5 v a p}-s_{5 l i q}\right)$

$\mathrm{Q}_{\mathrm{E}}=\dot{m}_{\mathrm{R} 22}\left(\mathrm{~h}_{6}-\mathrm{h}_{5^{\prime}}\right)$

The cooling load of $6.59 \mathrm{~kW}$ is obtained from the production company catalog of the appliance.

$\mathrm{Q}_{\mathrm{E}}=\dot{m}_{\mathrm{R} 22}\left(\mathrm{~h}_{5}-\mathrm{h}_{4^{\prime}}\right)$

In order to find the energy of the points (from 1-6), Q is calculated by using the following Formula 15 .

$Q(n)=\dot{m}_{R 22} \times h(n)$

The data of measurement points of the applied system are given in Table 10 [10]. Table 10 shows the $Q$ data as a result of the measuring points.

Compressor load can be found using Formula 16.

$W_{\text {comp }}=\dot{m}_{R 22}\left(h_{2}-h_{1}\right)$

Where the COP of the appliance is calculated by the ratio of the evaporator load to the compressor load using the following Formula 17. 


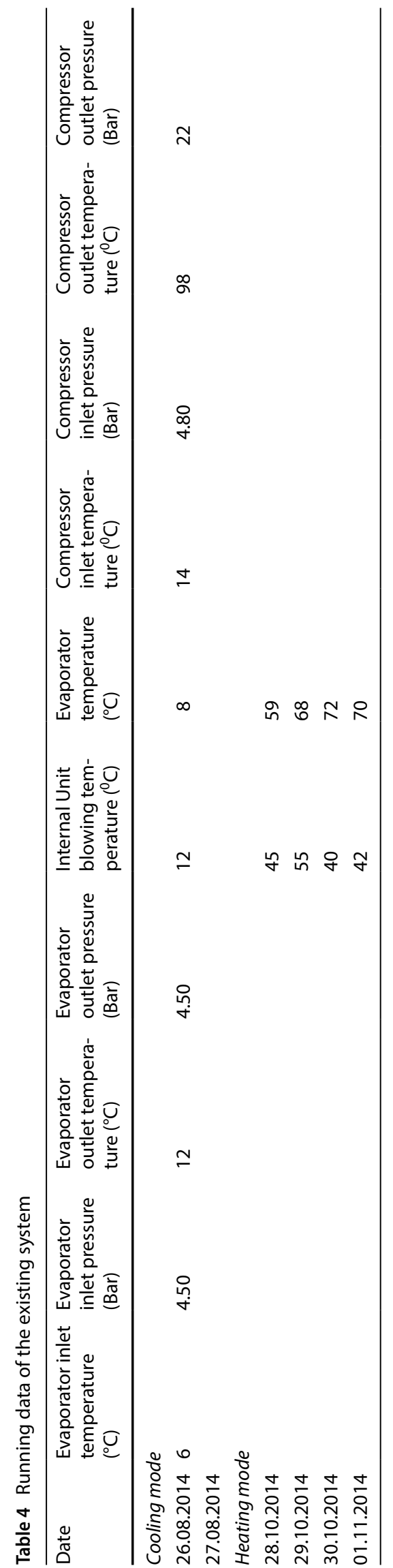

Table 5 Reference values

Reference values, $\mathrm{T}_{0}$ and properties

\begin{tabular}{ll}
\hline $\mathrm{T}_{0}$ & $298.15 \mathrm{~K}$ \\
$\mathrm{~h}_{0}$ & $429.53 \mathrm{~kJ} / \mathrm{kg}$ \\
$\mathrm{s}_{0}$ & $1.98 \mathrm{~kJ} / \mathrm{kg} \mathrm{K}$ \\
\hline
\end{tabular}

\section{COP Values of the Appliance}

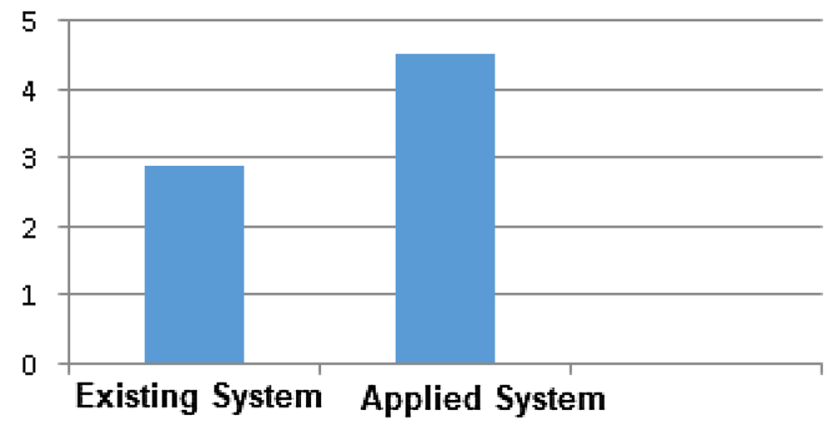

Fig. 2 COP values of the appliance

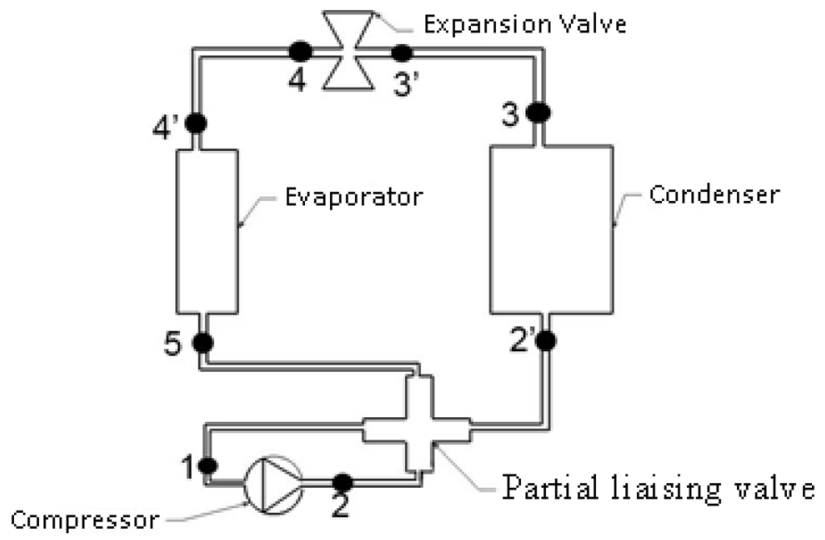

Fig. 3 Measuring points for the existing system

$C O P_{\text {applied system }}=\frac{\dot{Q}_{\text {Evap }}}{W_{\text {Comp }}}$

COP and corresponding values for the existing system can be seen in Table 11.

The data showing the $Q$ of the system for the cases with and existing system are shown in Fig. 5. Fig 5 shows the thermal energy values of the boiler system are continuously positive according to existing system (without boiler system's usage). This efficiency is especially noticeable in the input and output of the compressor and evaporator where a lot of energy is spent. From catalog data, $50 \mathrm{~L}$ boiler consumes an average of $1.5 \mathrm{~kW} /$ 
Table 6 Data of measurement points for existing system

\begin{tabular}{lllllll}
\hline Points & Equipment & $\mathrm{T}(\mathrm{C})$ & $\mathrm{P}(\mathrm{Bar})$ & $\mathrm{m}(\mathrm{kg} / \mathrm{s})$ & $\mathrm{h}(\mathrm{kJ} / \mathrm{kg})$ & $\mathrm{s}(\mathrm{kJ} / \mathrm{kg} \mathrm{K})$ \\
\hline 1 & Compressor inlet & 14 & 4.80 & 0.05151 & 415.77 & 1.792 \\
2 & Compressor outlet & 98 & 22 & 0.05151 & 459.99 & 1.798 \\
$2^{\prime}$ & Condenser inlet & 95 & 22 & 0.05151 & 457.26 & 1.791 \\
3 & Condenser outlet & 43 & 21 & 0.05151 & 253.68 & 1.178 \\
$3^{\prime}$ & Expansion valve inlet & 43 & 21 & 0.05151 & 253.68 & 1.178 \\
4 & Expansion valve outlet & 6 & 4.50 & 0.05151 & 253.68 & 0.803 \\
$4^{\prime}$ & Evaporator inlet & 6 & 4.50 & 0.05151 & 253.68 & 0.803 \\
5 & Evaporator outlet & 12 & 4.50 & 0.05151 & 381.61 & 1.532 \\
\hline
\end{tabular}

Table 7 Values obtained from the appliance and calculations

\begin{tabular}{llllllll}
\hline Points & Equipment & $\mathrm{T}(\mathrm{C})$ & $\mathrm{P}(\mathrm{Bar})$ & $\mathrm{m}(\mathrm{kg} / \mathrm{s})$ & $\mathrm{h}(\mathrm{kJ} / \mathrm{kg})$ & $\mathrm{s}(\mathrm{kJ} / \mathrm{kg} \mathrm{K})$ & $\mathrm{Q}(\mathrm{kW})$ \\
\hline 1 & Compressor inlet & 14 & 4.80 & 0.05151 & 415.77 & 1.792 & 21.4167 \\
2 & Compressor outlet & 98 & 22 & 0.05151 & 459.99 & 1.798 & 23.6942 \\
$2^{\prime}$ & Condenser inlet & 95 & 22 & 0.05151 & 457.26 & 1.791 & 23.5535 \\
3 & Condenser outlet & 43 & 21 & 0.05151 & 253.68 & 1.178 & 13.0672 \\
$3^{\prime}$ & Expansion valve inlet & 43 & 21 & 0.05151 & 253.68 & 1.178 & 13.0672 \\
4 & Expansion valve outlet & 6 & 4.50 & 0.05151 & 253.68 & 0.803 & 13.0672 \\
$4^{\prime}$ & Evaporator inlet & 6 & 4.50 & 0.05151 & 253.68 & 0.803 & 13.0672 \\
5 & Evaporator outlet & 12 & 4.50 & 0.05151 & 381.61 & 1.532 & 19.6572 \\
\hline
\end{tabular}

Table 8 COP and corresponding values for the existing system

\begin{tabular}{llllll}
\hline $\begin{array}{l}\dot{m} R 22 \\
(\mathrm{~kg} / \mathrm{s})\end{array}$ & $\mathrm{h}_{1}(\mathrm{~kJ} / \mathrm{kg})$ & $\mathrm{h}_{2}(\mathrm{~kJ} / \mathrm{kg})$ & $\dot{Q}_{\text {Evap }}(\mathrm{kW})$ & $\begin{array}{l}\mathrm{W}_{\text {comp. }} \\
(\mathrm{kW})\end{array}$ & COP \\
\hline 0.05151 & 415.77 & 459.99 & 6.59 & 2.27 & 2.8941 \\
\hline
\end{tabular}

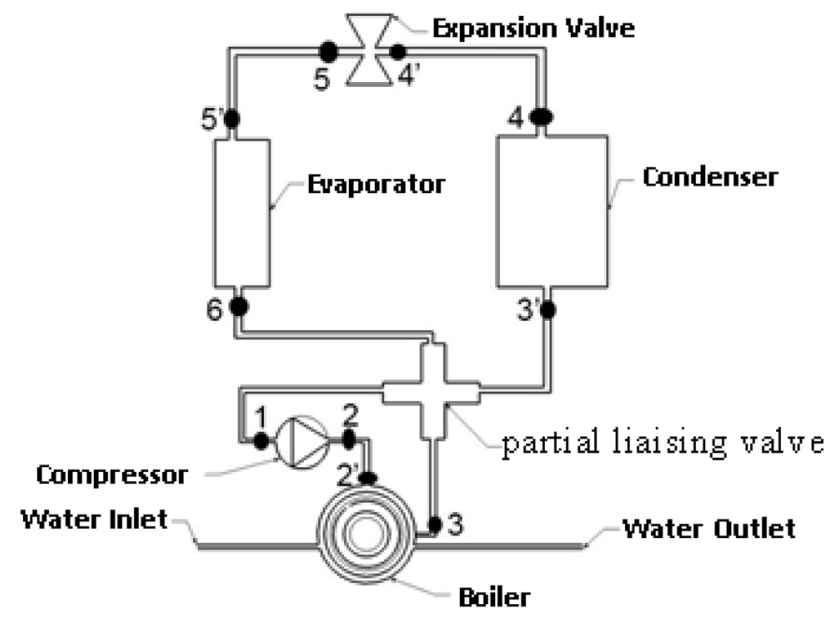

Fig. 4 Measurement points for the applied system

day electricity during stable operation. According to this information, the average annual electricity consumption of a boiler is calculated as follows.
The average annual electricity consumption of a boiler for $50 \mathrm{~L}$ can be calculated using the Formula 18:

\section{Total Electric Consumption}

$$
=\text { Average daily consumption } \times \text { day } / \text { year }
$$

The differences (existing and applied system) in the electrical consumption of the devices is shown in Fig. 6 .

The average annual electricity consumption cost of a boiler can be calculated using the Formula 19;

$$
\begin{aligned}
& \text { Electric Consumption Cost } \\
& \quad=\text { Average electric consumption } \times \text { electric cost }
\end{aligned}
$$

The average annual saving of the boiler; the average annual electricity consumption of a boiler is obtained by saving the electricity in the cooling of the device during the operation of the boiler. The average annual savings of the boiler can be calculated using the Formula 20;

$$
\begin{aligned}
& \text { Average saving } \\
& =\text { Air conditioner saving }+ \text { cost of electricity consumption }
\end{aligned}
$$

The graph of the annual electrical advantage of the device in hot water production is shown in Fig. 7.

The amount of daily savings achieved through the total annual savings of the device is divided by 360 days according to Formula 21. 
Table 9 Measurement points and data for the applied system with s data
Table 10 Measured and calculated values from the applied system with $\mathrm{Q}$ data

\begin{tabular}{lllllll}
\hline Points & Equipment & $\mathrm{T}(\mathrm{C})$ & $\mathrm{P}(\mathrm{Bar})$ & $\mathrm{m}(\mathrm{kg} / \mathrm{s})$ & $\mathrm{h}(\mathrm{kJ} / \mathrm{kg})$ & $\mathrm{s}(\mathrm{kJ} / \mathrm{kg} \mathrm{K})$ \\
\hline 1 & Compressor inlet & 12 & 4.50 & 0.03878 & 414.913 & 1.794 \\
2 & Compressor outlet & 90 & 22 & 0.03878 & 452.289 & 1.778 \\
$2^{\prime}$ & Boiler inlet & 90 & 22 & 0.03878 & 452.289 & 1.778 \\
3 & Boiler outlet & 43 & 21 & 0.03878 & 405.618 & 1.643 \\
$3^{\prime}$ & Condenser inlet & 43 & 21 & 0.03878 & 405.618 & 1.643 \\
4 & Condenser outlet & 35 & 19 & 0.03878 & 243.101 & 1.145 \\
$4^{\prime}$ & Expansion valve inlet & 35 & 19 & 0.03878 & 243.101 & 1.145 \\
5 & Expansion valve outlet & 4 & 6 & 0.03878 & 243.101 & 1.153 \\
$5^{\prime}$ & Evaporator inlet & 4 & 6 & 0.03878 & 243.101 & 1.153 \\
6 & Evaporator outlet & 8 & 4 & 0.03878 & 413.048 & 1.798 \\
\hline
\end{tabular}

\begin{tabular}{llllllll}
\hline Points & Equipment & $\mathrm{T}(\mathrm{C})$ & $\mathrm{P}($ Bar $)$ & $\mathrm{m}(\mathrm{kg} / \mathrm{s})$ & $\mathrm{h}(\mathrm{kJ} / \mathrm{kg})$ & $\mathrm{s}(\mathrm{kJ} / \mathrm{kg} \mathrm{K})$ & $\mathrm{Q}(\mathrm{kW})$ \\
\hline 1 & Compressor inlet & 12 & 4.50 & 0.03878 & 414.913 & 1.794 & 16.089 \\
2 & Compressor outlet & 90 & 22 & 0.03878 & 452.289 & 1.778 & 17.5383 \\
$2^{\prime}$ & Boiler inlet & 90 & 22 & 0.03878 & 452.289 & 1.778 & 17.5383 \\
3 & Boiler outlet & 43 & 21 & 0.03878 & 405.618 & 1.643 & 15.7286 \\
$3^{\prime}$ & Condenser inlet & 43 & 21 & 0.03878 & 405.618 & 1.643 & 15.7286 \\
4 & Condenser outlet & 35 & 19 & 0.03878 & 243.101 & 1.145 & 9.42668 \\
$4^{\prime}$ & Expansion valve inlet & 35 & 19 & 0.03878 & 243.101 & 1.145 & 9.42668 \\
5 & Expansion valve outlet & 4 & 6 & 0.03878 & 243.101 & 1.153 & 9.42668 \\
$5^{\prime}$ & Evaporator inlet & 4 & 6 & 0.03878 & 243.101 & 1.153 & 9.42668 \\
6 & Evaporator outlet & 8 & 4 & 0.03878 & 413.048 & 1.798 & 16.0167 \\
\hline
\end{tabular}

Table 11 COP and corresponding values for the existing system

\begin{tabular}{llllll}
\hline $\begin{array}{l}\dot{m} R 22 \\
(\mathrm{~kg} / \mathrm{s})\end{array}$ & $\mathrm{h}_{1}(\mathrm{~kJ} / \mathrm{kg})$ & $\mathrm{h}_{2}(\mathrm{~kJ} / \mathrm{kg})$ & $\dot{Q}_{\text {Evap }}(\mathrm{kW})$ & $\begin{array}{l}\mathrm{W}_{\text {comp. }} \\
(\mathrm{kW})\end{array}$ & COP \\
\hline 0.03878 & 414.913 & 452.289 & 6.59 & 1.449 & 4.5479 \\
\hline
\end{tabular}

The amount of daily saving

$=$ Total annual saving $\div$ days of a year
Payback period of the device (paying off period) can be calculated using the Formula 22;

Paying off period $=$ The initial investment cost $\div$ amount of saving

The data obtained from Formulas 18-22 are summarized in Table 12.
Fig. $5 \mathrm{Q}(\mathrm{kW})$ of the applied system and existing system
$\mathrm{Q}(\mathrm{kW})$ of the Applied System and Existing System

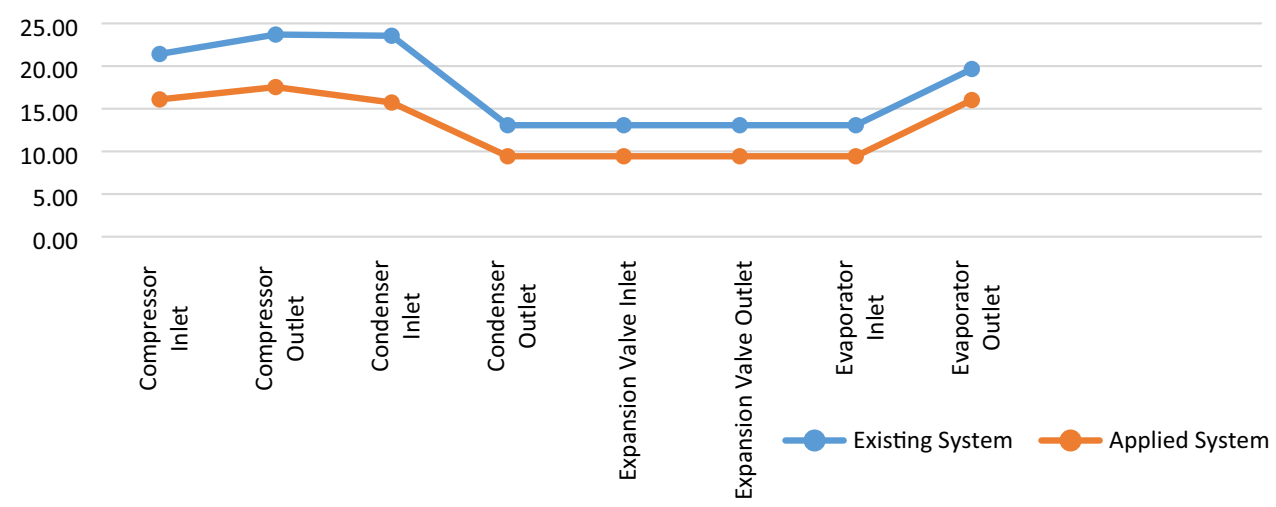




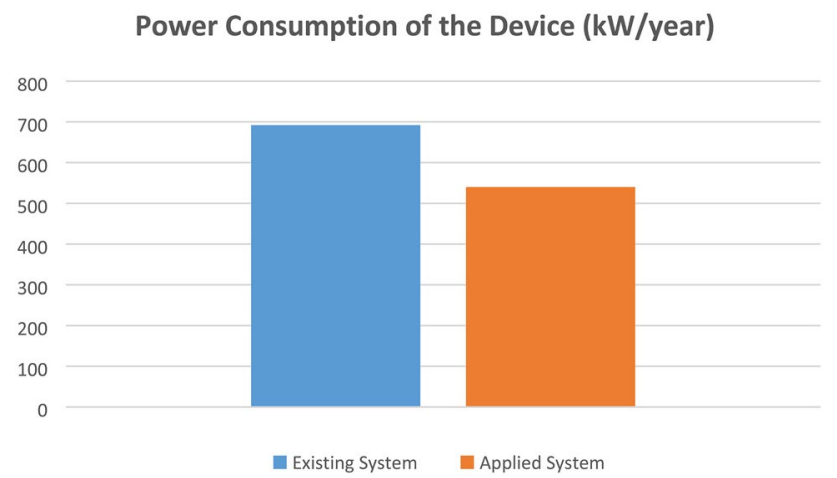

Fig. 6 Graph of electrical consumption of the existing and applied system in heating-cooling

An Annual Electricity Consumption of the Device (\$)

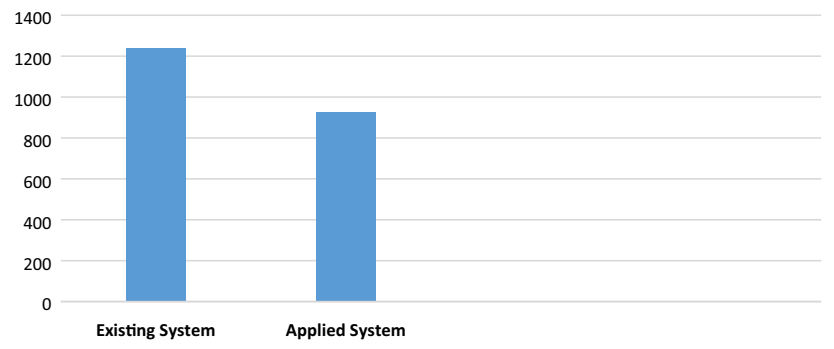

Fig. 7 The graph of the electrical advantage of the device in hot water production

Table 12 Data of the boiler consumption and saving amount

\begin{tabular}{|c|c|c|c|c|}
\hline $\begin{array}{l}\text { Electricity } \\
\text { consump- } \\
\text { tion of the } \\
\text { boiler (kW/ } \\
\text { year) }\end{array}$ & $\begin{array}{l}\text { Electricity } \\
\text { consump- } \\
\text { tion cost of } \\
\text { the boiler } \\
\text { (\$/Year) }\end{array}$ & $\begin{array}{l}\text { Consump- } \\
\text { tion cost } \\
\text { of air } \\
\text { conditioner } \\
\text { at cooling } \\
\text { load (\$/ } \\
\text { Year) }\end{array}$ & $\begin{array}{l}\text { Saving } \\
\text { amount of } \\
\text { the applied } \\
\text { system (\$/ } \\
\text { Year) }\end{array}$ & $\begin{array}{l}\text { Daily saving } \\
\text { amount of } \\
\text { the applied } \\
\text { system (\$/ } \\
\text { Day) }\end{array}$ \\
\hline 40 & 79 & 233 & 312.50 & 0.87 \\
\hline
\end{tabular}

\section{Conclusions}

As a result of the above calculations and the results obtained, the COP at the time of normal operation of the appliance was 2.89 and the COP of the appliance modified with boiler at the time of operation was 4.54. The COP of the appliance increased approximately 1.6 times with the boiler modification. This enabled the device to achieve a significant increase in efficiency while reducing electricity consumption and increasing capacity, allowing the use of hot water without any additional expense. The device provided us some advantages after application. The performance and electricity consumption improved by $20 \%$. While the initial investment cost of similar existing systems on the market is $\geq 5909$ USD, the use of split air conditioners, which are already used in residences, did not cost an extra amount. Thus, the cost of the modified appliance with the boiler was 172 USD. While many models in the market require a system room, there is no such requirement with this appliance. This increases its applicability in the market, allowing more distribution among the masses. In current models in the market, the user needs to program the timing of the hot water using the controller and the appliance needs to operate with the boiler system during the programmed times. This created difficulty in operation for users; however, the controller must be set only once and does not require any further adjustments, which makes this appliance user-friendly. The available appliances cannot perform heating-cooling functions in the building while operating with the boiler system. This causes loss in the comfort and regime of the building, and the appliance continues to consume electricity. However, the modified appliance does not cause such problems because the boiler and heating-cooling functions were performed simultaneously, thereby improving the performance of the appliance without consuming additional electricity. The initial investment cost of $139 \$$ devices, is paying off in a short period of 161 days. This situation gives users a cost advantage. After paying off the device at this stage as all the studies have reported daily $0.87 \$$ /day profits, while about $312.5 \$$ per year was reported from this study.

We have provided savings to both the environment and the users by using the domestic hot water for heating in commercial type split air conditioners with this application. If this and similar studies increases, we will both protect our environment and provide savings.

Author contributions All authors did test the design and implementation. The manuscript was written through the contributions of all authors. All authors have given approval to the final version of the manuscript.

\section{Compliance with ethical standards}

Conflict of interest The authors declare that they have no conflict of interest.

\section{References}

1. Ayhan T, Çomaklı O, Kaygusuz K (1992) Experimental investigation of the exergetic efficiency of solar assisted and energy storage heat pump systems. Energy Convers Manag J 33:165-173 
2. Bilgen $\mathrm{E}$, Takahashi $\mathrm{H}$ (2002) Exergy analysis and experimental study of heat pump systems. Exergy Int J 2:259-265

3. Bonnet S, Alaphilippe M, Stouffs P (2005) Energy, exergy and cost analysis of a micro-cogeneration system based on an ericsson engine. Int J Therm Sci 44(12):1161-1168

4. Ceylan I, Aktas M, Dogan H (2007) Determination of drying time of lumber in a heat pump dryer. Gazi Univ J Eng Arch 22:847-854

5. Esen H, Inallı M, Esen M, Pıhtılı K (2007) Energy and exergy analysis of a ground-coupled heat pump system with two horizontal ground heat exchangers. Build Environ 42:3606-3615

6. Hepbasli A, Akdemir O, Hancioglu E (2003) Experimental study of a closed loop vertical ground source heat pump system. Energy Convers Manag 44(4):527-548

7. Kaynakli O, Kilic M (2007) Theoretical study on the effect of operating conditions on performance of absorption refrigeration system. Energy Convers Manag 48:599-607

8. de Oliveira S (2013) Exergy, exergy costing, and renewability analysis of energy conversion processes. In: de Oliveira S Jr (ed) Exergy. Production, cost and renewability. Green Energy and Technology, pp 5-53. Springer, London. https://doi. org/10.1007/978-1-4471-4165-5_2
9. Ozgener L, Hepbasli A, Dincer I (2006) Effect of reference state on the performance of energy and exergy evaluation of geothermal district heating systems Balcova example. Build Environ 41(6):699-709

10. Sansli B (2015) The effect of condenser waste heat on boiler use in commercial type split air conditioner on energy efficiency. Master thesis, Institute of Science and Technology, Karabük University, Karabük

11. Taheri K, Gadow R, Kilinger A (2014) Exergy analysis as a developed concept of energy efficiency optimized processes: the case of thermal spray processes. Procedia CIRP 17:511-516. https://doi.org/10.1016/j.procir.2014.01.060

12. Yilmaz T, Aydin K (1985) Theoretical modeling of heat pumps. In: 5th national congress on heat science and technique, 18-22 Sept, Proceedings, vol 1, pp 329-340

Publisher's Note Springer Nature remains neutral with regard to jurisdictional claims in published maps and institutional affiliations. 